\title{
Análise do conhecimento dos acadêmicos das áreas biológicas e saúde sobre o dogma "DNA - RNA - Proteína"
}

\author{
Analysis of the knowledge of students of biological and health areas on the "DNA - RNA - Protein" dogma
}

Vera Regina Medeiros Andrade ${ }^{1}$, Keli Jaqueline Staudt ${ }^{2}$, Sandra Wilhelm Moerschbacher ${ }^{1}$, Ediele Ricardo Ajala $^{1}$, Tanise Maria Fiorin ${ }^{1}$, Antonio Vanderlei dos Santos ${ }^{1 *}$, Ivani Teresinha Lawall ${ }^{3}$

${ }^{1}$ Universidade regional Integrada do Alto Uruguai e das Missões (URI), Santo Ângelo-RS, Brasil.

${ }^{2}$ Universidade Federal do Rio Grande do Sul (UFRGS), Porto Alegre-RS, Brasil.

${ }^{3}$ Universidade do Estado de Santa Catarina (UDESC), Joinville-SC, Brasil.

*vandao@santoangelo.uri.br

Support: CNPq

\begin{abstract}
The central dogma of "DNA-RNA" describes the transfer of information from DNA to protein synthesis through RNA intermediates. It is not a simple process, and it suggested that this representation adds confusion to its understanding. To try to solve the confusion, the objective of this study was to follow the process of constructing concepts of the central dogma of biology by undergraduate students of health and biological sciences. The students (a total of $n=58$ ) answered questionnaires and developed conceptual maps, to evaluate learning. As a result, we observe that there is lack of understanding of this dogma by students, especially when $68 \%$ responded that doubling DNA does, creates or transforms into RNA. In concept maps, 32\% used correct concepts, hierarchy and representative keywords. We conclude that conceptual maps as a didactic and evaluative resource of learning can be used, because students cite concepts by making relationships between them, thus consolidating knowledge.
\end{abstract}

Keywords: Deoxyribonucleases; Molecular Biology; Education.

\section{Resumo}

O dogma "DNA-RNA" descreve a transferência da informação contida no DNA para síntese proteica, por um intermediário de RNA. Não é um processo simples, sendo sugerido que a representação causa confusão ao entendimento do processo. O objetivo foi acompanhar o processo de construção de conceitos do dogma central da biologia por acadêmicos dos cursos de graduação da área da saúde e das ciências biológicas. Os acadêmicos participantes que responderam a questionários e elaboraram mapas conceituais, para avaliar a aprendizagem. Como resultados, observamos que falta compreensão do dogma pelos estudantes, principalmente quando $68 \%$ responderam que DNA faz, cria ou se transforma em RNA. Nos mapas conceituais, $32 \%$ usaram conceitos corretos, hierarquia e palavras-chave representativas. Concluímos que os mapas conceituais podem ser utilizados como recurso didático e avaliativo da aprendizagem, porque os alunos citam conceitos fazendo relações entre eles, e nesse momento se consolida o conhecimento.

Palavras-chave: Desoxirribonucleases; Biologia Molecular; Aprendizagem 
Pesquisa em ensino: Análise do conhecimento dos acadêmicos das áreas biológicas e saúde sobre o dogma "DNA - RNA - Proteína"

\section{Introdução}

A molécula de DNA está na base de quase todos os aspectos da vida humana, e associado a um contexto ambiental e social. Assim, os conceitos relacionados a essa molécula e ao fluxo de informações genéticas se tornaram essenciais para compreender questões que têm sido suscitadas pela aplicação de novas tecnologias nos mais diversos contextos. A estrutura desta molécula foi sugerida por James D. Watson e Francis H. Crick [1]; baseados em diversas contribuições de cientistas que os precederam, possibilitaram essa aclamada descoberta. Anos depois, Watson e Crick postularam o dogma central da biologia referindo à informação genética, que é perpetuada em uma nova molécula de DNA, como também transferida para moléculas de RNA e depois traduzida em proteínas. O principal objetivo do dogma central era traduzir, numa ordem simples, as complexas relações entre as macromoléculas [1, 2, 3]. Entretanto, muitos estudantes apresentam dificuldades em compreender esses conceitos relacionados aos processos de duplicação, transcrição e tradução, principalmente quando são apresentados à figura canônica do dogma central (Figura 1) [4, 5].

\section{DNA $\Rightarrow$ RNA $\Longrightarrow$ Proteína}

Figura 1. Representação típica do dogma central.

O DNA é uma molécula que possui o código das informações genéticas em seus genes, formado por duas cadeias pareadas de nucleotídeos. Os nucleotídeos são unidades de um polímero, constituídos de uma molécula de açúcar (desoxirribose), um grupo fosfato (ácido fosfórico) e uma base nitrogenada, que pode ser adenina (A), guanina $(G)$, citosina $(C)$ e timina $(T)$ [6]. Essa molécula pode ter suas informações copiadas para formar novas moléculas de DNA pelo processo de duplicação, podendo, além disso, atuar como molde para a síntese de uma molécula de RNA por meio da transcrição. Já - no processo de tradução - o RNA mensageiro (mRNA) formado na transcrição é lido pelo RNA ribossômico (rRNA), com um conjunto de proteínas ribossômicas, e os RNAs transportadores (tRNAs), que se posicionam sobre o códon por um sítio; ao aminoácido por outro sítio: ambos formam uma proteína [6, 7].

A interpretação da figura canônica do dogma central (Figura 1) mostra que a informação genética (DNA) é usada para gerar moléculas mensageiras que são usadas para direcionar a síntese proteica. Ela sugere que o fluxo de informações ocorre por 
Pesquisa em ensino: Análise do conhecimento dos acadêmicos das áreas biológicas e saúde sobre o dogma "DNA - RNA - Proteína"

mecanismos muito simples; na realidade, para que ocorra essa síntese, existem vários processos que apresentam extrema complexidade. Essa representação deveria ser entendida da mesma forma por todos, porém tem sido comprovado que muitos estudantes não a compreendem pelos significados inadequados que eles apresentam sobre o dogma central [5].

Nesse sentido, o papel do professor no processo de aprendizagem do aluno é de extrema importância, já que aquele deve levar em conta que os alunos recebem informações das mais variadas fontes tais como o que é veiculado na internet, em propagandas, em noticiários. Essas informações nem sempre são cientificamente corretas; é papel de a escola transmitir informações fundamentadas cientificamente [8].

Na maioria das vezes, o aprendizado ocorre por memorização, que tem relação com o sistema cognitivo, mas de uma forma arbitrária e literal. Com isso o indivíduo não apresenta a aquisição de novos significados [9], o qual acrescenta que uma nova informação sobre determinado conceito deve ser apresentada ao ouvinte, sabendo previamente seu conhecimento sobre o assunto, já que este servirá como uma base para os novos.

A interação entre os novos conhecimentos e a estrutura cognitiva do aluno proporcionará um aprendizado de mais qualidade. Assim, a aprendizagem significativa acontece quando os conhecimentos passam a significar algo para o aprendiz, e ele consegue explicá-los com suas próprias palavras [10].

Nessa direção, a motivação para o presente estudo recai sobre algumas pesquisas que concentram sua atenção na compreensão dos conceitos e processos de ensino de biologia. Tais estudos apresentados nas primeiras etapas de um curso introdutório em biologia celular, para estudantes [11], relatam a necessidade de evoluirmos na pesquisa do ensino de genética e em outras áreas do conhecimento humano; como exemplo, a área da saúde. Por conseguinte, objetivamos nesse estudo acompanhar o processo de construção de conceitos do dogma central da biologia por acadêmicos dos cursos de graduação da área da saúde e das ciências biológicas.

Sabemos que o conhecimento não formalmente expresso é difícil de ser exposto, o que dificulta sua transmissão e compartilhamento com outras pessoas. Algumas das formas de exteriorizar esses conhecimentos se dão pela elaboração de um resumo e da confecção de mapas conceituais.

Os mapas conceituais são esquemas utilizados para representar um conjunto de significados que estão inclusos dentro de alguns processos [12]. Podem ser utilizados 
como recurso didático e avaliativo da aprendizagem, já que - além de citar conceitos demonstram a relação entre eles. Eles não são autoexplicativos; portanto, requerem uma explicação por parte de quem os faz [10].

$O$ artigo é estruturado em duas seções. Na primeira, explicamos a metodologia que usaremos a fim de alcançar o objetivo de analisar a compreensão dos conceitos do dogma central da biologia por acadêmicos dos cursos de graduação da área de saúde e de ciências biológicas; na segunda, detalhamos a análise dos resultados.

\section{Metodologia}

A pesquisa é de natureza qualitativa. O projeto de pesquisa foi aprovado pelo Comitê de Ética em Pesquisa da Instituição, conforme o Parecer número 1.057.728. Os participantes foram selecionados conforme os seguintes critérios de inclusão: serem acadêmicos dos cursos de bacharelado em Biologia e dos cursos de Enfermagem e Farmácia; estarem matriculados nas disciplinas de Biologia Celular e Genética Humana, independente de idade, cor, raça, sexo, nacionalidade e estado civil, em uma Universidade Comunitária da Região das Missões, noroeste do estado do Rio Grande do Sul, Brasil, não havendo critério de exclusão. Os participantes foram convidados e esclarecidos sobre os objetivos, métodos, procedimentos e outros aspectos da pesquisa, e os que concordaram em participar assinaram o termo de consentimento livre e esclarecido (TCLE) 1 .

Esse estudo foi realizado em duas etapas, compreendendo o período de agosto de 2015 a julho de 2017. Participaram da pesquisa 58 graduandos no início do semestre e 29 graduandos no fim do semestre, na primeira etapa da pesquisa foi aplicado um questionário (Figura 2) para identificar as concepções dos alunos a respeito do dogma central da Biologia [13]. Na segunda etapa, participaram 25 graduandos, quando foi apresentado e explicado um mapa conceitual sobre o dogma central da Biologia, e foi solicitada a eles a elaboração de mapas conceituais.

Na primeira etapa, o questionário foi composto por quatro questões abertas, o que possibilitou ao participante expressar seu conhecimento [13] sem a influência de respostas pré-estabelecidas. No enunciado do questionário, estava apresentada uma figura do dogma central da Biologia (Figura 2), que visava a contribuir para reflexão e elaboração das respostas, aplicado em dois momentos diferentes: no início e no final das

1 TCLE:1057.728. 
disciplinas. Os acadêmicos foram identificados como A1, A2, A3 até A58 (início), B1, B2, B3 até B29 (final), na primeira etapa da pesquisa.

\section{DNA $\Rightarrow$ RNA $\Rightarrow$ Proteína}

\section{Essa figura do "dogma central" da biologia representa a relação entre os processos envolvidos no fluxo de informações genéticas.}

Responda as seguintes questões:

- $O$ que é biologia molecular?

- $\mathrm{O}$ que vocês pensam que as setas da figura representam?

- O que acontece entre o DNA e o RNA?

- Qual o significado do processo de duplicação, transcrição e tradução?

Figura 2. Representação do instrumento de coleta dos dados da primeira etapa da pesquisa.

Para a discussão dos resultados, as respostas foram classificadas pela análise de conteúdo proposta por Bardin [14]. Em cada questão, as respostas foram classificadas e agregadas por categorias conforme apresentassem termos ou fragmentos das frases que representassem a unidade do significado.

Para a pergunta: "o que estuda a Biologia Molecular?", considerando que a Biologia Molecular estuda a interação entre as moléculas da célula, partindo do DNA, RNA e a síntese de proteínas. As respostas foram classificadas e agrupadas conforme apresentassem as seguintes categorias: estudo de moléculas; estudo do DNA, RNA e proteínas; estudo dos genes; estudo da célula.

Na segunda pergunta: "O que vocês pensam que as setas representam?", foram consideradas: duplicação, transcrição e tradução; e processo de síntese de proteínas. Já para a terceira questão: "O que acontece entre o DNA e o RNA?", extraíram-se respostas tais como transcrição de genes, formação da molécula de RNA a partir de informações contidas no DNA, associação de diferentes nucleotídeos para formar a molécula de RNA.

Ainda, para a questão: "Qual o significado do processo de duplicação, transcrição e tradução?", foram consideradas as categorias: duplicação ou síntese de nova molécula de 
Pesquisa em ensino: Análise do conhecimento dos acadêmicos das áreas biológicas e saúde sobre o dogma "DNA - RNA - Proteína"

DNA, transcrição é a cópia da informação do DNA ou síntese da molécula de RNA e para tradução: leitura da molécula de RNA ou síntese de proteínas.

Após a análise das respostas fornecidas pelos participantes, foi confeccionado para a segunda etapa da pesquisa - um material didático com os conceitos envolvidos no estudo de biologia molecular e sobre o dogma central, levando em consideração os conhecimentos prévios dos alunos e buscando sempre uma linguagem simples e acessível.

O modelo de material didático corresponde a um mapa conceitual (Figura 3) para mostrar os diversos processos e relações existentes entre os conceitos. O programa utilizado para a elaboração do mapa conceitual foi o Cmap tools: uma ferramenta disponível, de livre acesso na web [15].

$\mathrm{Na}$ segunda etapa da pesquisa, o mapa conceitual elaborado pelas pesquisadoras sobre o dogma central da biologia (Figura 3), foi apresentado aos acadêmicos, com uma explanação sobre o assunto. Após a apresentação desse mapa, os acadêmicos receberam instruções de como construir um mapa conceitual, tais como: a) apresentar os conceitos em nível de hierarquia dos mais gerais para os específicos; b) conectar os conceitos com linhas e colocar nessas linhas palavras-chave que expliquem a relação entre os conceitos, de tal forma que se possam transmitir significado a leitura; c) colocar, se possível, exemplos e figuras embaixo dos conceitos [10].

Durante a construção dos mapas conceituais, os alunos foram orientados para não se preocuparem com o mapa do colega, pois cada um pode fazer um mapa diferente do outro sem que isto represente acerto ou erro. Após essa explanação, os acadêmicos elaboraram - individualmente - seus mapas conceituais, expressando seus conhecimentos sobre o tema. Para a análise dos mapas conceituais, foram elencados alguns critérios, tais como: representatividade do conteúdo dos conceitos em relação aos conteúdos abordados; os conceitos apresentados e níveis de hierarquia conceitual; interrelação entre os conceitos, quantidade e qualidade das palavras-chave [16].

Após a construção dos mapas conceituais por parte dos alunos, os mapas foram analisados e interpretados conforme os critérios de análise, levando em conta as seguintes categorias que foram elaboradas a partir dos resultados: conceitos e hierarquias representativos; conceitos representativos sem hierarquia; conceitos não representativos sem hierarquia; quantidade de palavras-chave e qualidade de palavraschave, sendo que um único mapa pode cair em mais de uma categoria. 
Analysis of the knowledge of students of biological and health areas on the "DNA - RNA - Protein" dogma

Nessa etapa, os participantes da pesquisa foram identificados como C1, C2, C3 até C25.

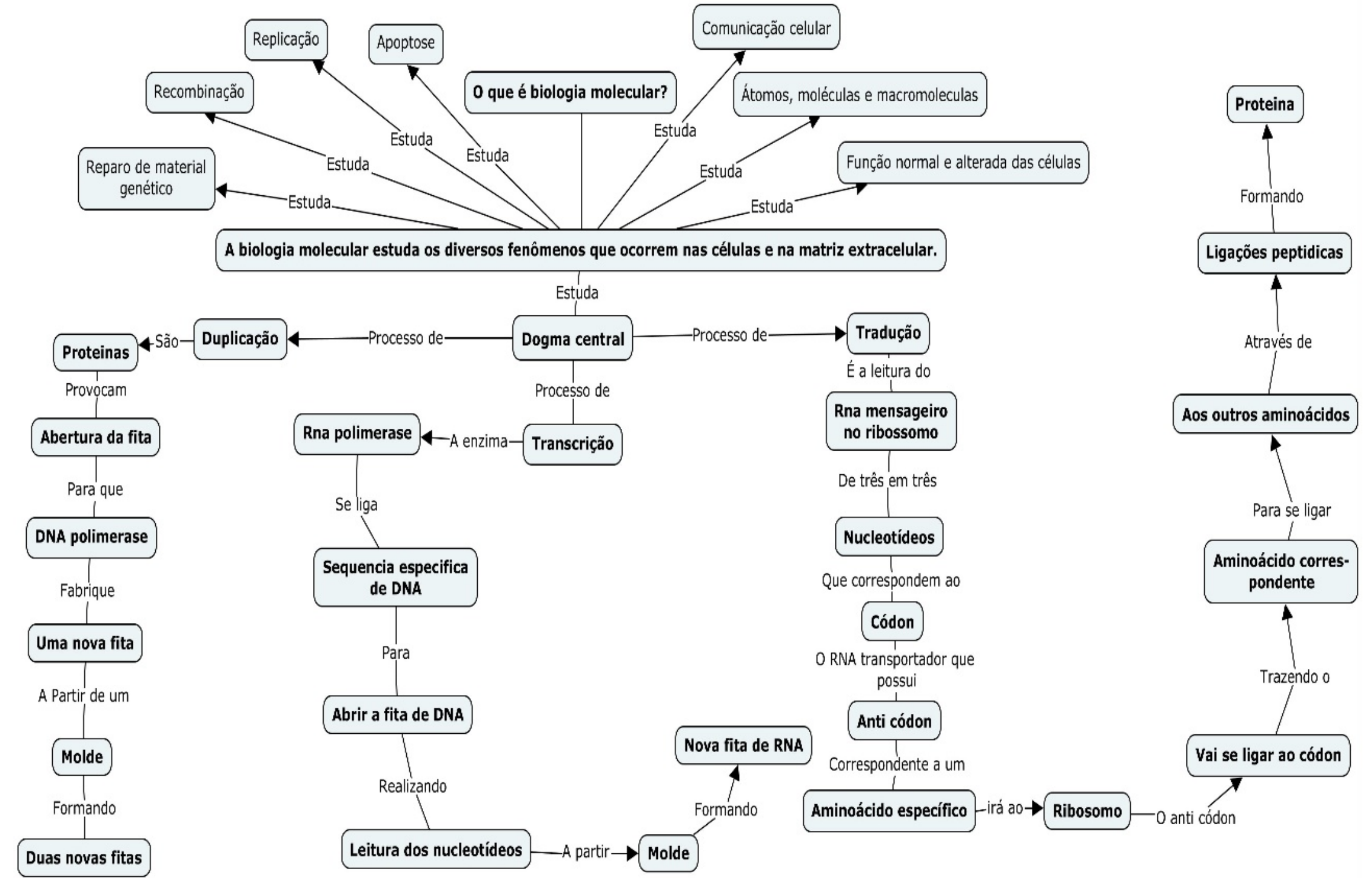

Figura 3. Mapa conceitual apresentando o "dogma central" da biologia, desenvolvido no Cmap Tools pelas pesquisadoras e apresentado aos acadêmicos na segunda etapa da pesquisa. 


\section{Análise e Discussão dos Resultados}

Depois que os alunos responderam ao questionário, foi realizada uma leitura de todo o material, direcionado às características das informações, às palavras e às ideias expressas. Para a pergunta "O que é biologia molecular?", no primeiro momento, a maioria respondeu conforme as categorias consideradas como corretas, como "Estuda as moléculas" (31\%) e "Estuda as moléculas de DNA, RNA e proteínas" (31\%), sendo que no segundo momento, no final da disciplina, esse percentual permaneceu semelhante (Figura 4). No entanto, as respostas de $37,9 \%$ dos acadêmicos demonstraram que não tinham uma compreensão sobre o que trata a biologia molecular, respondendo de forma incorreta ou ambígua.

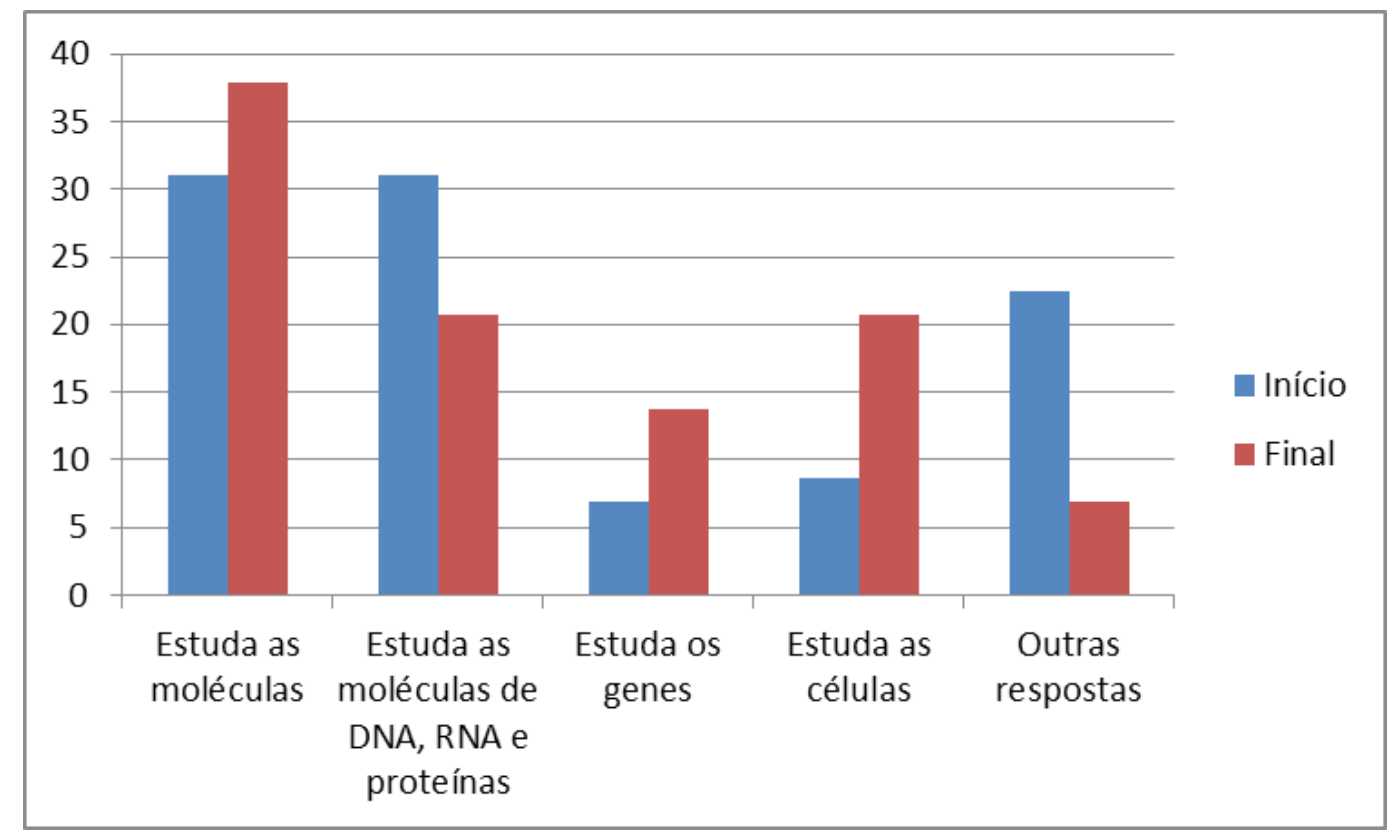

Figura 4. Resposta a pergunta: O que é biologia molecular? ( $n=58$ início e 29 final).

Semelhante ao ocorrido com o estudo realizado por Wright, Fisk e Newman [5], em quatro instituições localizadas no norte dos Estados Unidos, em que quase metade dos participantes, ao serem perguntados sobre o que era biologia molecular, os entrevistados se valeram de respostas incompletas ou sugeriram conexões incorretas entre o DNA e o RNA.

Com relação ao significado das setas, dos acadêmicos que participaram - 25,8\% no início e $48,3 \%$ no final (Figura 5) - responderam de forma correta à questão, porém nenhum deles questionou sobre as descobertas da transcrição reversa e modificações pós-transcricionais em outras moléculas de RNAs [7]. 


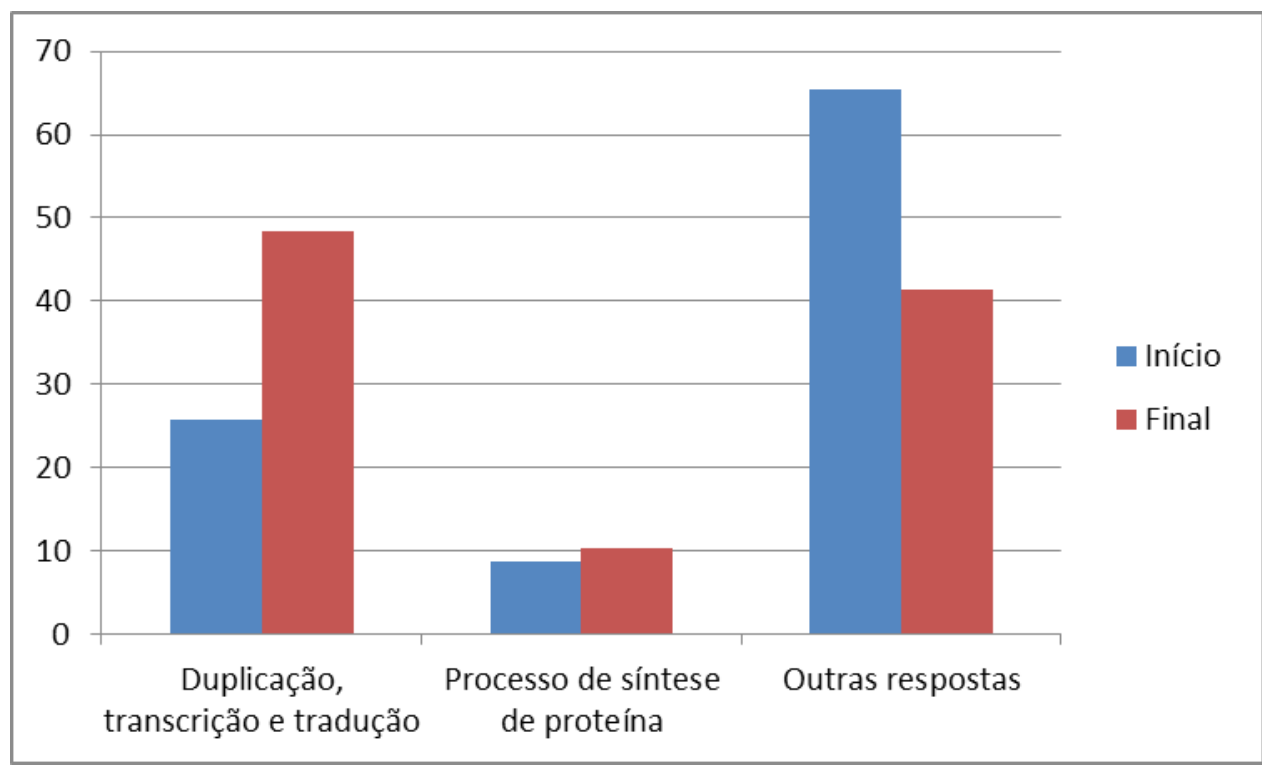

Figura 5. Resposta a pergunta: O que vocês pensam que as setas representam? ( $n=58$ início e 29 final).

Isto pode ser explicado porque a seta que representa a transcrição é representada por uma seta simples na representação do dogma central [5]. Mais da metade dos estudantes, no início, responderam de forma incorreta, como refletem algumas respostas descritas abaixo:

[A5] "O DNA se reproduz criando RNA e o DNA sintetizando a proteína". [A7, A11] "O DNA cria RNA a partir dele mesmo e após isso sintetiza proteínas". [A25] "O DNA comanda o RNA que fará a síntese de proteínas".

[ B12] "O DNA faz o RNA que faz a proteína".

[B17] "O DNA vira RNA, que se liga a uma proteína para ir para o resto do corpo".

Quando analisadas as respostas referentes aos questionários dos dois momentos, foi observado que os conceitos do dogma central não estão claros para os acadêmicos, principalmente quando observado que alguns deles responderam que o "DNA comanda ou faz ou vira ou se reproduz criando RNA que faz proteínas".

Quando os alunos respondem que o DNA se transforma em RNA, é percebido que eles estão pensando que as setas significam uma conversão química e não um entendimento que o DNA ou o segmento do DNA é o modelo para a síntese de uma outra molécula que é o RNA. Além disso, apresentaram outras respostas confusas, que podem ser consequência de uma aprendizagem mecânica por memorização, tais como:

[A4] "O DNA passa para o RNA que sintetiza a proteína".

[A6] "O DNA vai para o RNA e sintetiza a proteína".

[B13] "O RNA sai do DNA, e o DNA gira em torno do seu próprio DNA".

Os resultados do presente estudo são semelhantes aos do estudo realizado por Primon e Rezende [8], realizado com graduandos do curso de Licenciatura em Biologia: quando esses foram perguntados sobre o DNA, surgiram respostas como "O DNA se 
Pesquisa em ensino: Análise do conhecimento dos acadêmicos das áreas biológicas e saúde sobre o dogma "DNA - RNA - Proteína"

transforma em RNA ou vice-versa", assim como nesta pesquisa. Também se assemelham ao resultado da pesquisa realizada por Wright, Fisk e Newman [4], no qual os acadêmicos usaram algumas palavras como "transcrição" e "tradução", porém transmitindo um significado incorreto a respeito desses processos, sugerindo que o DNA foi convertido ou transformado em RNA durante o processo de transcrição.

Da mesma forma, quando questionados sobre "O que acontece entre o DNA e o RNA?" (Figura 6), esse não entendimento foi reforçado, uma vez que muitos estudantes usaram a terminologia correta para os processos, mas explicaram de forma incorreta. A maioria respondeu com afirmações tecnicamente incorretas ou ambíguas, não sendo possível saber ao certo o que os estudantes entendiam. Novamente, apareceram respostas como "DNA cria ou faz ou comanda ou forma o RNA" ou "DNA se transforma em RNA". O uso dos verbos fazer, criar ou transformar para significar o que acontece entre as moléculas indicam uma conversão química, demonstrando pouca compreensão do processo biológico.

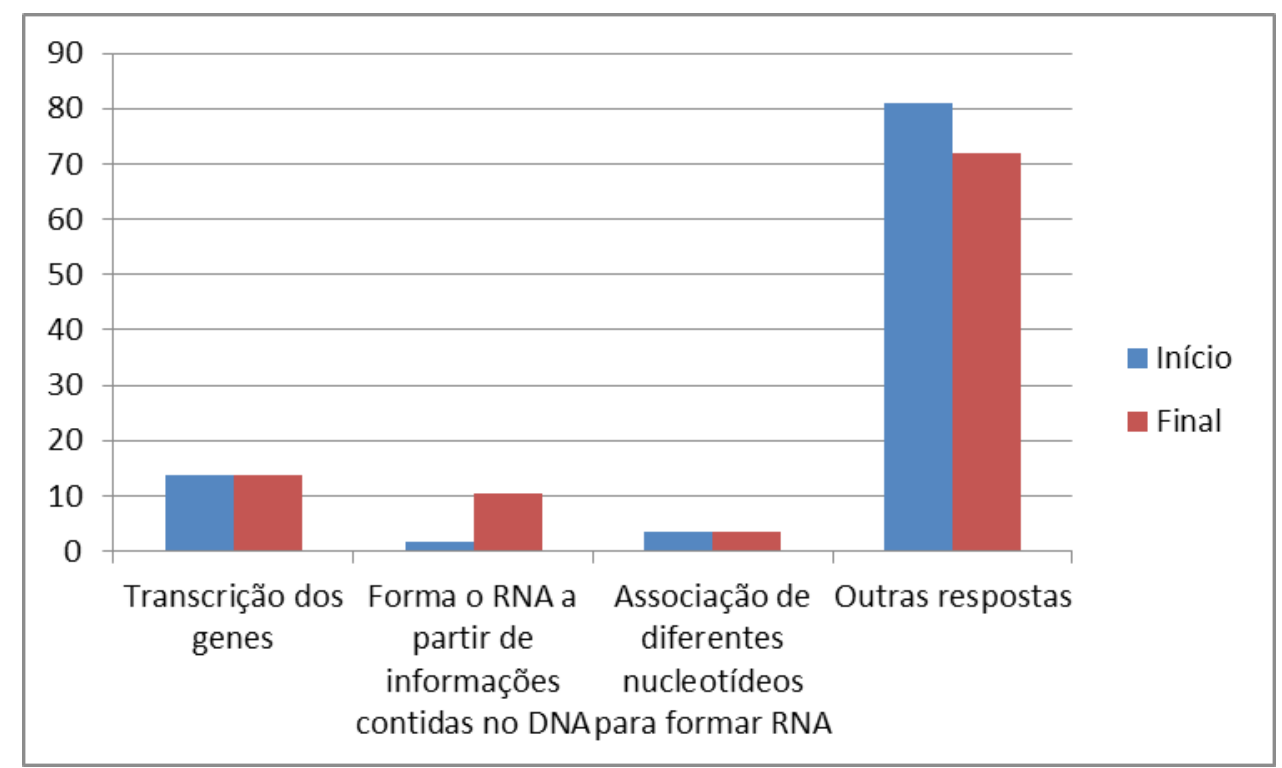

Figura 6. Resposta a pergunta: O que acontece entre o DNA e o RNA? ( $n=58$ início e 29 final).

Os dados se assemelham aos do estudo de Silva, Orlando, Cotulio e Gouvêa [17], realizado com graduandos de Ciências Biológicas, Biomedicina, Biotecnologia e Farmácia, de uma universidade de MG, em que as respostas em relação ao DNA foram muito variadas, e a maioria dos estudantes demonstraram que não conheciam os conceitos corretos da composição e estrutura do DNA.

Quando os acadêmicos responderam sobre o que entendiam sobre os processos de duplicação, transcrição e tradução (Figura 7), percebeu-se - novamente - que muitos utilizaram termos técnicos corretos, porém descreveram os processos de forma incorreta. 
Pesquisa em ensino: Análise do conhecimento dos acadêmicos das áreas biológicas e saúde sobre o dogma "DNA - RNA - Proteína"

Na resposta "na duplicação o DNA se divide para a síntese de RNA, transcrição é cópia do DNA levado ao ribossomo e tradução é a leitura do RNAm", foi observado que apesar de não estar totalmente incorreta a afirmação - essa ainda mostra que não existe uma total compreensão desses processos. Em outras respostas, não foi possível determinar o entendimento que os participantes tinham da questão, porque o uso de uma terminologia correta como duplicação, transcrição e tradução não necessariamente está correlacionado com o conceito. Foram observados muitos equívocos a respeito de como os acadêmicos pensam a respeito do fluxo de informações do dogma central da biologia molecular.

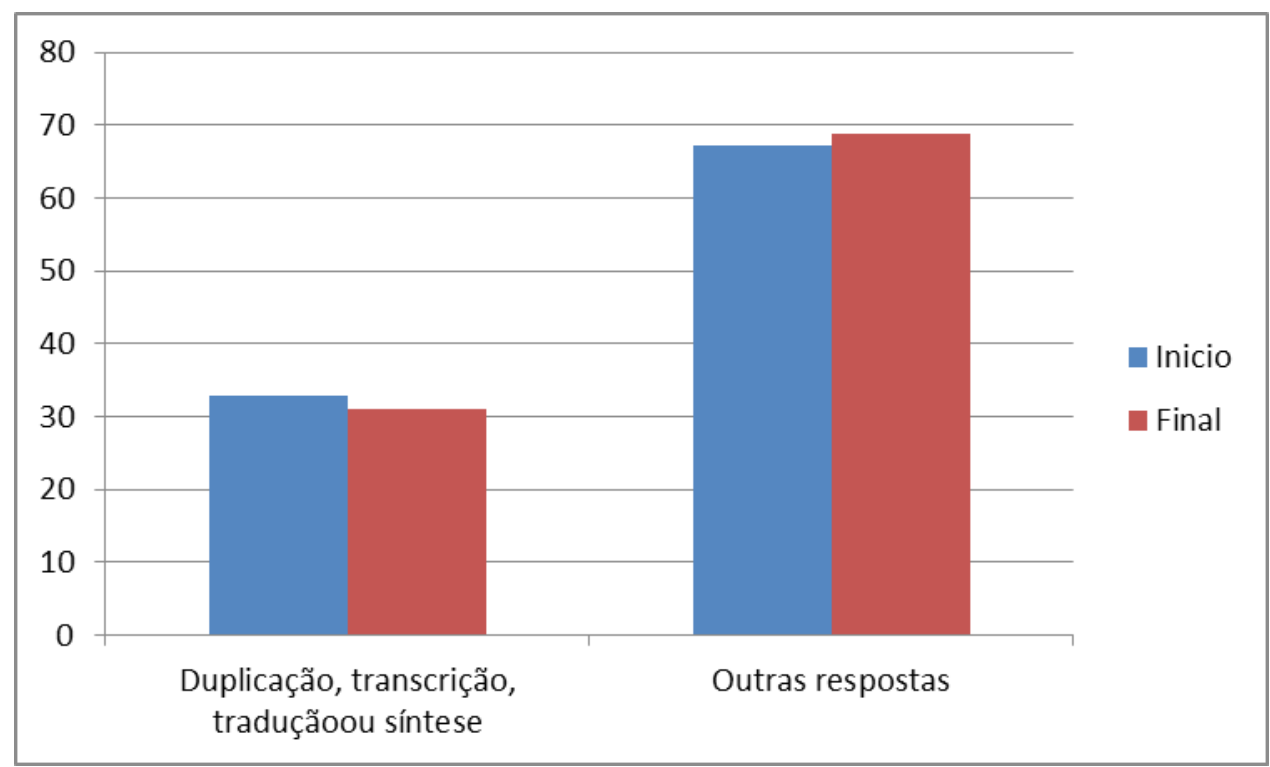

Figura 7. Resposta a pergunta: Significado do processo de duplicação, transcrição e tradução ( $n=$ 58 início e 29 final).

Esses dados estão compatíveis com a pesquisa realizada por Wright, Fisk e Newman [5], em que os estudantes também utilizaram linguagem ambígua ou responderam apenas com o termo adequado, sem explicar o processo em si, e os autores sugeriram que a representação canônica do dogma central adiciona confusão e não esclarecimento no entendimento desses processos por parte dos entrevistados.

Analisando os mapas conceituais elaborados pelos acadêmicos, na segunda etapa da pesquisa, foi observado - novamente - que a maioria utilizou terminologias corretas, mas acabou fazendo ligações ou explicações incorretas sobre esses processos.

A maioria dos estudantes que aceitou elaborar o seu próprio mapa conceitual fez o uso de conceitos corretos (80\%): Destes 32\% $(n=8)$ usaram conceitos corretos com hierarquia e palavras-chave representativas. Entre esses oito mapas conceituais, serão apresentados dois, como mostram as Figuras 8 e 9. 
Pesquisa em ensino: Análise do conhecimento dos acadêmicos das áreas biológicas e saúde sobre o dogma "DNA - RNA - Proteína"

Analisando o mapa conceitual do participante C20 apresentado na Figura 8, foi observado que seu autor soube diferenciar as moléculas de DNA e RNA quanto às bases nitrogenadas e açúcares que fazem parte de sua constituição. Entretanto, o participante C20 só citou os processos de duplicação, transcrição e tradução. Ligado ao RNA, o acadêmico, numa tentativa de explicar o processo de tradução, citou os três tipos de RNA existentes, porém como não fez o uso de palavras ou frases de ligação. Com isso, não se pode saber ao certo se - para ele - uma molécula de RNA vai se transformando na outra ou se representou uma sequência de eventos.

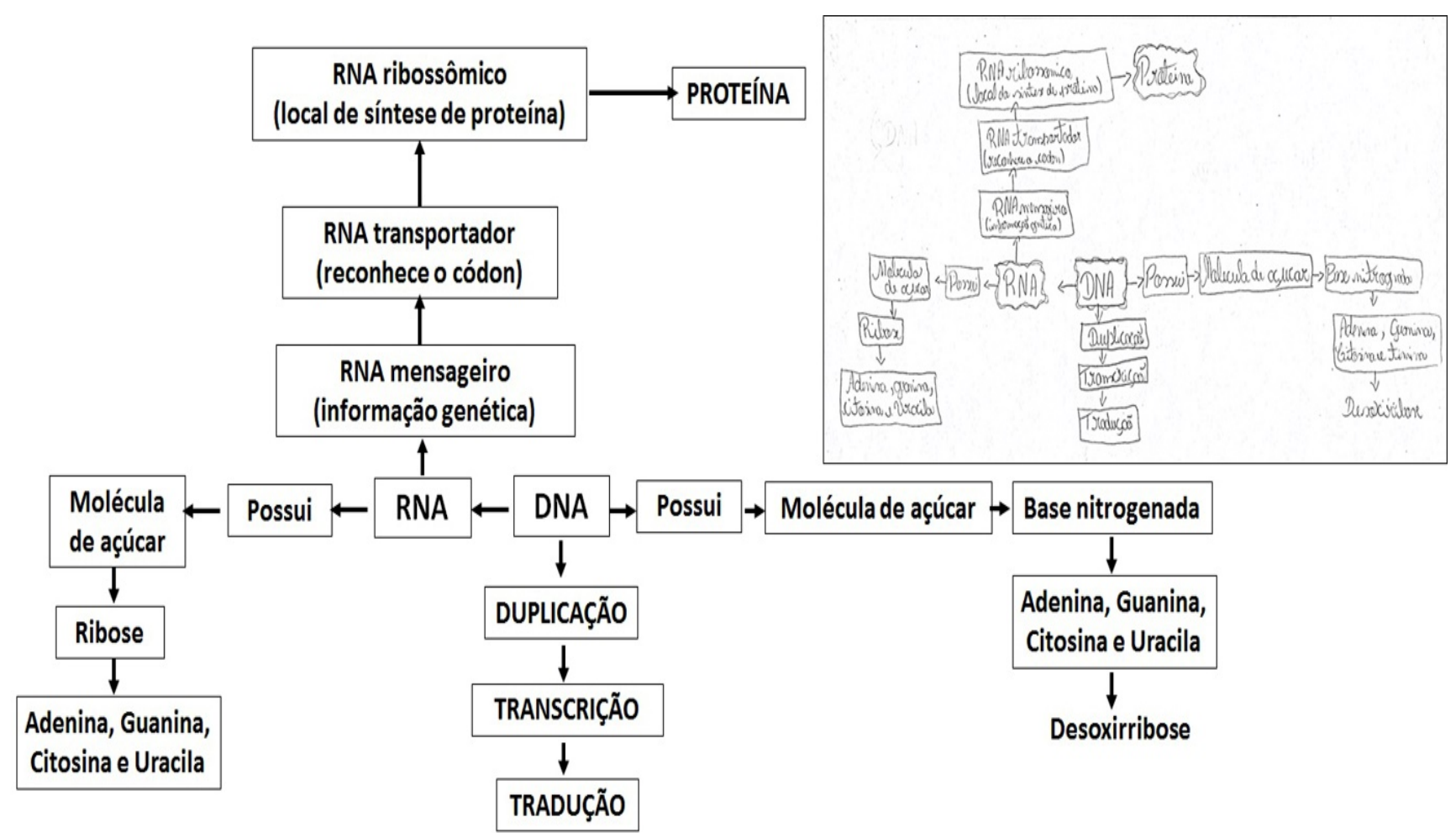

Figura 8. Mapa conceitual referente aos processos do dogma central elaborado por participante da pesquisa.

Fonte: Elaborada pelo acadêmico participante da pesquisa C20 (figura original no canto superior direito) e reproduzida pelos autores para melhorar a qualidade da imagem.

Neste mapa conceitual, elaborado pelo participante C25, apresentado na Figura 9, foi observado um maior domínio a respeito dos processos do fluxo de informações genéticas. 

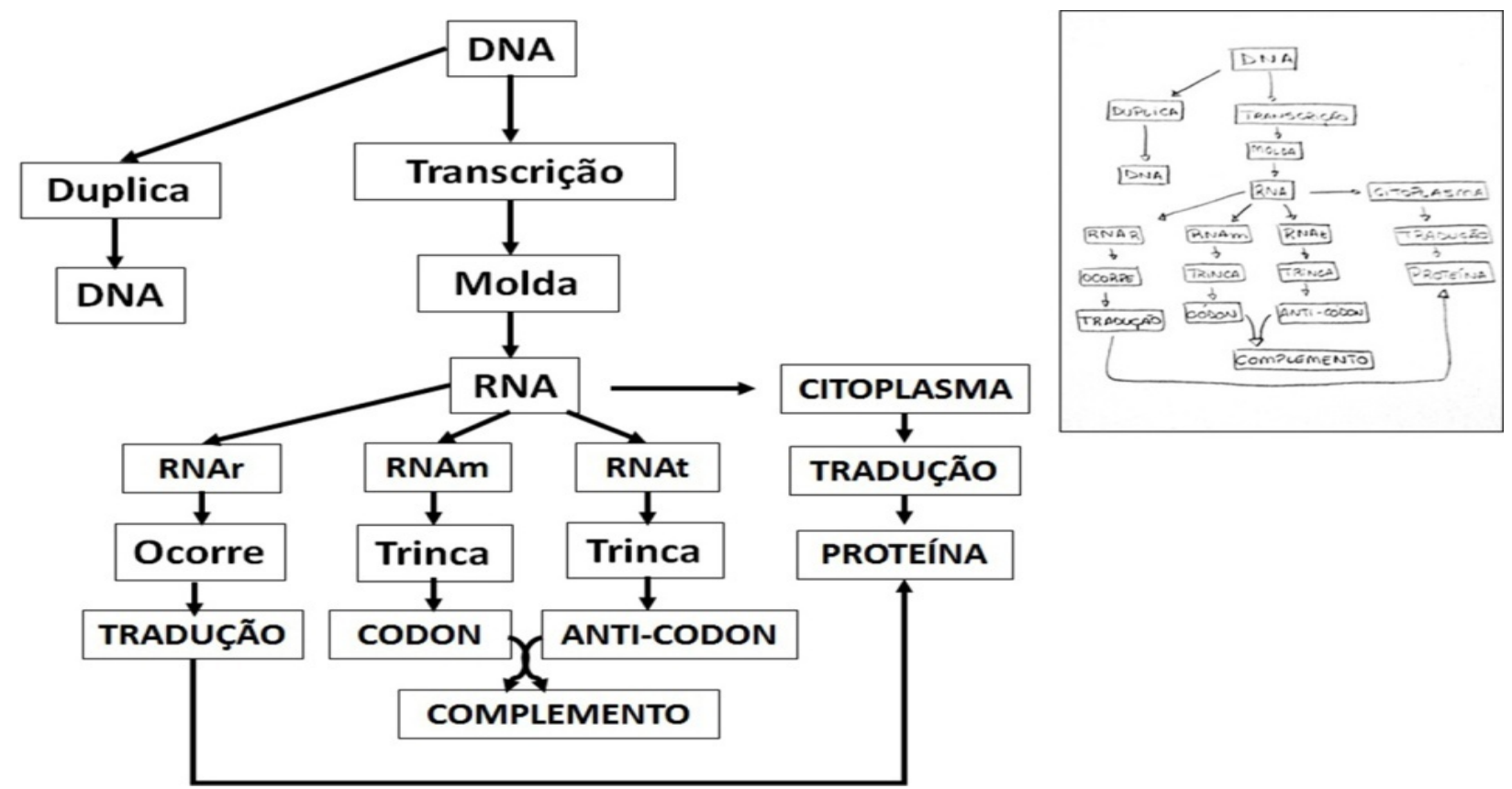

Figura 9. Mapa conceitual referente aos processos do dogma central elaborado por participante da pesquisa - Santo Ângelo, 2017.

Fonte: Elaborada pelo acadêmico participante da pesquisa C25 (figura original no canto superior direita) e reproduzida pelos autores para melhorar a qualidade da imagem.

O estudante soube dizer que: após a duplicação, surge mais uma molécula de DNA; que, no processo de transcrição, o DNA servirá como um molde para a formação de RNA; que existem três tipos de RNA onde o mRNA e o tRNA terão trincas de nucleotídeos chamado de códon e anticódon, respectivamente, sendo um complementar do outro, além de expor que é no rRNA que ocorre a tradução, e que o processo de tradução - que ocorre no citoplasma - dará origem a uma nova proteína.

\subsection{Dificuldades e limitações}

Quando foram realizadas as análises dos mapas conceituais, verificamos que não foram solicitadas - para os acadêmicos - explicações orais ou por escrito em relação ao seu mapa, sendo que os mapas conceituais não foram apresentados e discutidos entre os acadêmicos participantes do estudo. Se isso tivesse sido feito teria facilitado a tarefa de análise. Percebemos - portanto - que sem uma comunicação oral, não foi possibilitado uma reconstrução desse mapa, e não houve, por sua vez, a incorporação de palavraschave para transmitir significado entre os conceitos.

Sendo assim, sugerimos outros estudos sobre esse assunto com utilização de mapas conceituais, mas que os participantes apresentem e discutam seus mapas para que, desta forma, construam uma aprendizagem significativa. 


\section{Conclusão}

A partir dos dados obtidos, podemos considerar que a maioria dos acadêmicos sabe o que estuda a biologia molecular. Com relação ao significado das setas do dogma "DNA-RNA-Proteína", no início do semestre, a maioria respondeu de forma incorreta; no final do semestre, houve um crescimento uma vez que a maioria respondeu corretamente.

Porém, quando questionados sobre "O que acontece entre o DNA e o RNA?", a maioria respondeu de forma incorreta nos dois momentos da pesquisa; isso se repetiu para o significado das palavras "duplicação, transcrição e tradução", em que foi verificado que eles descreveram esses processos de forma incorreta.

$\mathrm{Na}$ maioria das vezes, o aprendizado ocorre por memorização, que tem relação com o sistema cognitivo de forma arbitrária e literal, sendo que o indivíduo não apresenta a aquisição de novos significados [9]. Nesse sentido, uma nova informação sobre determinado conceito deve ser apresentada ao ouvinte, sabendo - previamente - seu conhecimento sobre o assunto, já que esse servirá como uma base para os novos conhecimentos [9].

Após a apresentação do mapa conceitual sobre o "dogma central" da biologia, a maioria dos estudantes que elaborou seus mapas conceituais fez uso de conceitos corretos. Podemos observar pelos resultados que - em torno de um terço deles - usaram os conceitos corretos com hierarquia e palavras-chave representativas.

Além disso, constatamos que a interação entre os novos conhecimentos e a estrutura cognitiva dos alunos pode ter proporcionado um aprendizado significativo. Mapas conceituais são propostos como uma estratégia potencialmente facilitadora de uma aprendizagem expressiva, que acontece quando os conhecimentos passam a significar algo para o aprendiz e ele consegue explicá-los com suas próprias palavras [10].

Desta forma, reforçamos que mapas conceituais podem ser utilizados como recurso didático e avaliativo da aprendizagem, já que neles os alunos citam conceitos e fazem relações entre eles, além de explicarem. É nesse momento que se consolida o conhecimento. 
Pesquisa em ensino: Análise do conhecimento dos acadêmicos das áreas biológicas e saúde sobre o dogma "DNA - RNA - Proteína"

\section{Referências}

[1] Watson JD, Crick FH. Molecular structure of nucleic acids: a structure for deoxyribose nucleic acid. Nature. 1953; 171:737-38.

[2] Oliveira THG, Santos NF, Beltramini L .O DNA: uma sinopse histórica. Revista de Ensino de Bioquímica. 2004;2(1): A1-A16.

[3] Crick FH. Central dogma of molecular biology. Nature. 1970;227:561-63.

[4] Jann NP, Leite FM. Jogo do DNA: um instrumento pedagógico para o ensino de ciências e biologia. Ciências \& Cognição. 2010;15(1):282-93.

[5] Wright LK, Fisk JN, Newman DL. DNA $\rightarrow$ RNA: what do students think the arrow means?. CBE Life Sciences Education. 2014;13(2):338-48.

[6] Griffiths AF, Wessler SR, Carroll SB, Doebley J. Introdução à genética. $9^{a}$ ed. Rio de Janeiro: Guanabara Koogan; 2009.

[7] Snustad PD, Simmons MJ. Fundamentos da genética. 6a ed. Rio de Janeiro: Guanabara Koogan; 2013.

[8] Primon SFC, Rezende BD. Conhecimento de graduandos do último semestre de cursos de licenciatura em ciências biológicas sobre DNA e RNA. $7^{\circ}$ Encontro Nacional de Pesquisa em Educação em Ciências [Internet]. Florianópolis: Anais; 2009 [cited 04 June 2009]. Available from: http://posgrad.fae.ufmg.br/posgrad/viienpec/pdfs/1599.pdf

[9] Ausubel DP. Aquisição e retenção de conhecimentos: uma perspectiva cognitiva. Lisboa: Paralelo Editora; 2000.

[10] Moreira MA. Aprendizagem Significativa: a teoria e textos complementares. São Paulo: Livraria da Física; 2012.

[11] Yarden H, Marbach-Ad G, Gershoni JM. Using the concept map technique in teaching introductory cell biology to college freshmen. Bioscene. 2004;30(1):1-11.

[12] Galante CES. O uso de mapas conceituais e mapas mentais como ferramentas pedagógicas no contexto educacional do ensino superior. Saber. 2014;3:1-28.

[13] Gil AC. Métodos e técnicas de pesquisa social. $6^{\mathrm{a}}$ ed. São Paulo: Atlas; 2008.

[14] Bardin L. Análise de conteúdo. São Paulo: Edições 70; 2011.

[15] CmapTools. Organize seus pensamentos em esquemas gráficos [Internet]. c2017 [cited 04 June 2017]. Available from: https://cmaptools.softonic.com.br/

[16] Ruiz-Moreno L, Sonzogno MC, Batista SHS, Batista NA. Mapa conceitual: ensaiando critérios de análise. Ciência \& Educação. 2007;13(3):453-63.

[17] Silva MI, Orlando TC, Cotulio VRM, Gouvêa CMCP. Os conceitos de gene e DNA por alunos ingressantes na UNIFAL-MG e a efetividade da dramatização como estratégia de ensino de biologia molecular. Revista de Ensino de Bioquímica. 2014;12(2):24-36.

\section{Agradecimentos}

Os autores agradecem ao Conselho Nacional de Desenvolvimento Científico e Tecnológico - CNPq, pela Programa Institucional de Bolsas de Iniciação Científica PIBIC, patrocinador da pesquisa de iniciação científica. $E$, aos acadêmicos dos cursos de Biologia, Enfermagem e Farmácia. 